\title{
CERTAIN PECULIAR ASPECTS OF DIRECTORS' POWERS AND OBLIGATIONS UNDER THE BUSINESS CORPORATIONS ACT
}

*R. W. EWASIUK

\section{INTRODUCTION}

The topic of directors' powers and liabilities generally is one that has been addressed in several articles already' and it is not the purpose of this note to deal with the more general aspects of the topic. The purpose of this note, rather, is to point out some specific peculiarities of the Business Corporations Act as they relate to directors and which, though potentially of some practical importance, have gone largely unnoticed.

\section{DIRECTORS' CONTRACTS}

Both the Companies Act ${ }^{2}$ and The Business Corporations Act ${ }^{3}$ provide for restrictions on the ability of a director to vote in respect of a contract in which he has a direct or indirect interest. Both statutes also impose a requirement for disclosure of that interest but this requirement is quite independent of the question of when, if ever, such a director can actually cast a vote in his capacity as director of the corporation in respect of the particular contract.

Of course, there are a great many situations where a director (or an entity in which the director is interested) enters into contracts with his corporation and both statutes to varying degrees have recognized this. Section 92(4) of The Companies Act provides as follows:

92(4) Unless otherwise expressly provided in the Articles of Association of the company, no director shall vote in respect of any contract or proposed contract in which he is [interested] and if he does so vote, his vote shall not be counted.

Hence, the Companies Act provides that the shareholders can, through the enactment of appropriate provisions in the articles of association, give their directors as broad a power in respect of voting as the shareholders wish. Certainly, it has been a common practice in Alberta to provide for just such a possibility in the articles of association of companies governed by the Companies Act. Quite commonly the articles of association of a private company allow for voting to take place where there is no quorum of directors not so interested provided that the contract is subsequently confirmed by ordinary resolution of the shareholders.

Even in the absence of an exception in the articles of association, Section 92(5) of the Companies Act makes exceptions to the general prohibition contained in Section 92(4):

92(5) Subsection (4) does not apply

(a) in the case of a contract by or on behalf of the company to give to the directors or any of them security for advances or by way of indemnity,

- Of Reynolds, Mirth \& Cote, Edmonton.

1. See, for example, Mr. J.G. Smeltzer's paper, delivered to the Legal Education Society of Alberta Corporate Practice Seminar on January 5 and 6, 1984.

2. R.S.A. 1980 c. C-20.

3. S.A., 1981, c. B-15. 
(b) in the case of a private company when there is no quorum of directors in office who are not so interested, or

(c) in the case of a contract between the company and any other company when the interest of the director in that other company consists solely of his being a director or officer of that other company and the holder of not more than the number of shares in that other company requisite to qualify him as a director.

Of particular importance is the exception contained in Section 92(5)(b). If, for example, all of the directors of a corporation were interested in the proposed contract then in the absence of Section 92(5)(b) (and in the absence of an enabling provision in the articles of association) the directors of the company would effectively be precluded from making any decisions at all with respect to the matter. In view of that, Section $92(5)(b)$ would appear to be a sensible, if not an essential, provision.

At first glance, the comparable sections of the Business Corporations Act appear to provide for even broader exceptions. Section 115(5) of the Business Corporations Act provides as follows:

115(5) A director referred to in Subsection (1) [i.e. an interested director] shall not vote on any resolution to approve the contract unless the contract is

(a) an arrangement by way of security for money lent to or obligations undertaken by him, or by a body corporate in which he has an interest, for the benefit of the corporation or an affiliate,

(b) a contract relating primarily to his remuneration as a director, officer or agent of the corporation or an affiliate,

(c) a contract for indemnity or insurance under section 119, or

(d) a contract with an af filiate.

It may be that Section 115(5)(d) was intended to replace Section 92(5)(b) of the Companies Act. However, upon closer examination, it becomes apparent that Section 115(5)(d) is nowhere near as generous as Section 92(5)(b) and in effect is quite narrow. ${ }^{4}$ An "affiliate" is defined in Section 2(b) of The Business Corporations Act as being another body corporate which is either a parent or subsidiary or is controlled by the same person. The term does not, for example, include shareholders who are individuals. It is not difficult to conceive of contracts, therefore, which would not fall within any of the exceptions outlined in Section 115(5).

It may be that Section 115(7) was intended to prevent a contract from being attacked on the basis of an inability of the directors to vote. Section $115(7)$ reads as follows:

115(7) If a material contract is made between a corporation and one or more of its directors or officers, or between a corporation and another person of which a director or officer of the corporation is a director or officer or in which he has a material interest,

(a) the contract is neither void nor voidable by reason only of that relationship, or by reason only that a director with an interest in the contract is present at or is counted to determine the presence of a quorum at a meeting of directors or committee of directors that authorized the contract, and

4. In fact, while the exceptions are narrower, so is the general prohibition. Section 92(1) of the Companies Act concerns itself with contracts in which a director is "in any way, directly or indirectly, interested". Hence Section 92(4) would, in certain circumstances, apply to contracts of indirect benefit to the director or another entity in which he holds an interest even though neither he nor the other entity is a party to the contract. Section 115(1) of the Business Corporations Act, on the other hand, concerns itself only with the case where the director (or an entity in which he is an officer or director or in which he has a material interest) is actually a party to the contract. 
(b) a director or officer or former director or officer of the corporation to whom a profit accrues as a result of the making of the contract is not liable to account to the corporation for that profit by reason only of holding office as a director or officer,

if the director or officer disclosed his interest in accordance with subsection (2), (3), (4) or (6), as the case may be, and the contract was approved by the directors or the shareholders and it was reasonable and fair to the corporation at the time it was approved.

However, Section 115(7) does not speak of voting and provides only that the contract is neither void nor voidable "by reason only of that relationship or by reason only that a director with an interest in the contract is present at or is counted to determine the presence of a quorum." The general inability to vote would appear to be unaltered. The most that can be said about Section 115(7) is that where there is otherwise an inability to collect together a sufficient number of directors to constitute a quorum (by reason of the fact that there are a number of interested directors who cannot vote) the contract may yet be saved by allowing less than a quorum to vote in respect of the contract. However, in a situation where all the directors are interested, it would not be the lack of quorum that would present a problem, but the inability of the directors to vote at all. Further, Section 115(7) only operates if the other tests are satisfied; namely the disclosure of interest in accordance with the other provisions of Section 115 and, most importantly, the provision that the contract be reasonable and fair to the corporation. In many situations, this latter test may be difficult if not impossible to satisfy.

The problem is compounded by the failure to give any definition to the term "material interest" in Section 115(1)(b). Does a director, for example, have a material interest in a corporation of which he is a major creditor or with which he has a material contract?

Assuming that all of the directors (or, where Section 115(7)(a) does not apply, some number leaving less than the quorum of directors ${ }^{5}$ ) are interested in a contract that does not fall within the exceptions in Section 115(5), then it is impossible for the corporation to enter into that contract on the authority of a resolution of the directors. The reason, quite simply, is that the corporation cannot, through its directors, resolve to do so. It cannot make an offer to enter into that contract nor can it accept one. The question that then arises is whether or not, in the absence of an appropriate unanimous shareholder agreement, such a material contract can be entered into at all.

Under the Companies Act it is fairly well established that where the directors are unwilling or unable to vote, the power to decide the matter reverts more or less automatically to the shareholders in general

5. Section 109(2) of the Business Corporations Act establishes the quorum as being the majority of the fixed number or the minimum number of directors, as the case may be, specified in the articles of incorporation and business cannot be transacted without that quorum. The provisions of Section 109 can, however, be replaced by bylaws, and it is common (and, whatever quorum is established it is suggested, of ten prudent) for the bylaws to allow for less than a quorum to transact business at an adjourned meeting if the reason for the adjournment is a lack of quorum at the original meeting. 
meeting. ${ }^{6}$ Where the shareholders and directors are the same persons (or where such a resolution can be easily obtained, if not implied) then such a rule would, in practice, remove a good deal of concerns in many cases. However, the applicability of this principle to a Business Corporations Act company is sufficiently unclear as to cause some considerable concern in this respect and certainly there is an argument to be made that there is no such power in the shareholders. The theoretical basis for the exercise of directors' powers under the Companies Act goes something like this. A group of persons decide they want to carry on business as a limited liability company. The appropriate documents are filed and as soon as the company is incorporated these people become shareholders according to their respective interests. At some point in time, usually prior to incorporation, these persons enter into an agreement concerning, among other things, the management of the business and affairs of the company. This agreement is called the Articles of Association and by filing it as such certain statutory provisions as to future amendments to this agreement become applicable. Normally the shareholders agree, through the vehicle of the articles of associaion, that they will not run the corporation themselves but rather will appoint directors for that purpose. The extent of the directors' powers, usually quite broad, are then set out in the articles. Hence, the power to manage the business and affairs of the corporation rests with the shareholders in the first instance. It is only through the agreement of the shareholders, initially unanimous, that the directors acquire any powers at all. Now, if the directors cannot carry out these powers then logic dictates that the power reverts back to the shareholders since it is they who held the power initially, and their design of having the directors exercise these powers has been frustrated.

Under the Business Corporations Act, however, the situation is in reverse. Section 97(1) states that "subject to any unanimous shareholder agreement, the directors shall manage the business and affairs of the corporation." Hence, under the Business Corporations Act the powers of the directors are granted statutorily in the first instance. There is nothing in the Business Corporation Act which gives any power of management to the shareholders short of their ability to unanimously agree to abrogate the authority of the directors under section $140(1)(c)$ and to pass by-laws of general application by ordinary resolution. If the directors are unable to vote on a matter, therefore, there is at least an argument to be made, and hence a significant risk, that the shareholders cannot by ordinary resolution cause the company to agree to a contract or ratify any contracts in respect of which all directors were prohibited from voting. The only cure may be by way of unanimous shareholder agreement. Indeed, this may be implied from section 140(1)(c). Even if this is incorrect, and there is a reversion of powers to shareholders in general meeting then there will in some cases be a further difficulty in that, as a practical mat-

6. Irvine v. Union Bank of Australia (1877) 2 App. Cas. 366, P.C.; Grant v. U.K. Switchback Rys. (1888) 40 Ch. D. 135, C.A.; Barron v. Potter [1914] 1 Ch. 895; Fosterv. Foster [1916] 1 Ch. 532 . 
ter, such meetings are unlikely to be held and signed resolutions in lieu thereof are unlikely to be obtained. ${ }^{7}$

To take a simple case, consider the situation where individual $\mathrm{A}$ is a $50 \%$ shareholder in A Ltd. but is the sole director. Assume, further, that $A$ is a director or shareholder or has a material interest in B Ltd. It is suggested that the following are examples of material contracts which, in the absence of an appropriate unanimous shareholder agreement, cannot be entered into at all, or at the very least without specific steps being taken to obtain the approval of the shareholders of A Ltd.:

1. A contract for the issuance of shares from A Ltd. to A or to B Ltd. (even at the organizational level ${ }^{8}$ ) or from B Ltd. to A Ltd. An issue of shares in exchange for consideration (and consideration is required under Section 25 of the Business Corporations Act) does, after all, comprise a contract between a company and the shareholder.

2. An agreement made pursuant to Section 85 of The Income Tax Act ${ }^{9}$ pursuant to which property of A or of B Ltd. is rolled into A Ltd. without incurring an immediate tax liability.

3. Any sale, lease or mortgage of land or goods from or to A or B Ltd. to or from A Ltd.

4. Any agreement respecting a loan from A or B Ltd., including any contract of debenture or other form of security.

In fact if the shareholders of a Business Corporation Act company do not have a reversionary power then the above examples as between $A$ and A Ltd. would be equally suspect where A was the sole shareholder/ director of A Ltd.

For corporations with a relatively small number of shareholders there is, fortunately, a very easy way of dealing with the problem. Section 115(9) of the Business Corporations Act makes all of these voting restrictions subject to the provisions of a unanimous shareholder agreement. Quite simply, then, all that is required is that a simplified form of unanimous shareholder agreement be entered into ${ }^{10}$ which specifically permits voting in appropriate situations. It is suggested that it would be prudent for an agreement of this nature to be entered into upon in-

7. Obviously, where the directors and shareholders are the same persons and if there is a reversionary power in the shareholders, there is unlikely to be a problem. A decision of the directors will also be a decision of the shareholders, albeit in a different capacity.

8. Where a client acquires a "shelf" company from his solicitor, then normally it is the solicitor who is director at the time of issuance and the problem does not arise. However, where a corporation is incorporated on instructions from clients it is most common, for reasons of convenience and self-protection, for the clients or their nominees and not the solicitors to be appointed directors at the time of incorporation. In view of the difficulties that this might lead to, this practice might not be so convenient or prudent after all. The directors may be unable to vote to issue shares to themselves or to parties in which they have an interest. Hence, unless at least one of the proposed shareholders is independent, there may be no shareholders at all, and if there are no shareholders, then there will be no one who can validate the directors acts by shareholder's resolution (even if this is possible) and no one who can cure the problem by unanimous shareholder agreement.

9. S.C. 1970-71-72, c. 68.

10. The definition of "unanimous shareholder agreement" in Section l(z) of the Business Corporations Act specifically contemplates the situation where there is only one shareholder. 
corporation or continuation as a matter of course and more or less as a matter of corporate constitution."1

An alternative method would be to clarify, by unanimous shareholder agreement, that the shareholders do have a reversionary power either at their discretion or when the directors are unable or unwilling to act. However, this method would not remove the necessity of having to hold shareholders meetings, or of having to obtain signed resolutions in lieu thereof and, hence, the former method would appear to be the most convenient. This is not to say, however, that such a reversionary clause would not be prudent in any event.

It is worth noting that there can be no such thing as an implied or oral unanimous shareholder agreement. Section 1(z) of the Business Corporations Act specifically requires that a unanimous shareholder agreement be in writing. Similarly, the contract itself would not likely be sufficient to comprise the necessary unanimous shareholder agreement. First, all shareholders would have to be a party to the agreement and, although that test would be satisfied in many cases, it would not follow in all situations. Second, in order for a contract to be a unanimous shareholder agreement as defined in Section 1(z), it must provide "for any of the matters enumerated in Section 140(1)" and that, once again, would not necessarily follow and, indeed, is unlikely to be the case. An alternative might be to specifically provide in such contracts as they arise (and assuming that all shareholders are a party to the contract) that the directors can vote in respect of that contract. The difficulty with this alternative, however, is that this clause would form part of a larger contract and the question that arises is whether or not this contract can be entered into in the first place without the directors being given the authority to vote on the matter beforehand. Also, there is the purely practical point that the inclusion of such a clause is very likely to be forgotten, or omitted by persons unaware of the concern. Hence, it is suggested that the most prudent practice would be to provide for simplified unanimous shareholder agreements as a matter of course and to provide for such contracts in the same way that the articles of association used to. The writer's observation, however, has been that such agreements are rare.

The concern is more than a theoretical one. Consider, for example, the position of a lender who has advanced money to a corporation pursuant to an agreement of loan to which the corporation and all its directors are a party ${ }^{12}$ or on the security of an assignment of a contract (such as a mortgage, agreement for sale or lease) between the corporation and another entity in which its directors have an interest. Query whether the contract of loan in the former case is not also a contract in which the directors are interested and, if so, whether the corporation had ever agreed to the terms of the loan. Query also whether, in such a case, the indoor management rule would apply and whether the fact of the directors' interest, apparent to the innocent party, is sufficient to put the inno-

11. However, a unanimous shareholder agreement would not necessarily cure any of the problems associated with directors issuing shares to themselves at the organizational level. See note 8, supra.

12. Many guarantees, incidentally, purport to have this result by making the guaranteeing shareholder or director a principal obligor. 
cent party on inquiry. ${ }^{13}$ Query whether Sections 16 and 18 of the Business Corporations Act are broad enough to protect the lender in this situation either. ${ }^{14}$ Consider also whether Revenue Canada would not be able to attack a particular transaction based upon a contract in respect of which all directors were prohibited from voting. ${ }^{15}$ Consider further whether following a sale of their shares the former shareholders could not subsequently be required to account to the corporation (now owned by someone else) for property or money received in pursuance of what was essentially a non-existent contract.

\section{THE CREATION OF "SUPER LIMITED”' COMPANIES}

The Business Corporations Act, as does the Companies Act, provides for a number of situations where directors can be liable for certain things in certain situations, notwithstanding the general principle of limited liability. For example, directors may be liable in the following situations:

1. Directors may be liable for up to six months of the company's employees' salaries and wages. ${ }^{16}$

2. Where the directors have authorized the payment of dividends, the redemption of shares, the issue of shares or the re-purchase of shares when the corporation was unable to satisfy the solvency tests outlined in the Act, or when these steps are otherwise taken improperly, the directors may be liable to account to the company or its creditors. ${ }^{17}$

3. Even under the Companies Act, directors owed a general fiduciary obligation toward the company. This obligation may or may not have been expanded under the new Act and in particular under Section $117(1)$.

13. Obviously, in most of the situations where this concern is going to arise, the contracting parties are going to have actual knowledge (supplemented by a deemed knowledge of the law) of any lack of voting authority or ratification.

14. Section 16(3) speaks only of acts "of a corporation" which are contrary to the articles or to the Act itself. This may not be a situation where anything has been done contrary to either. Rather, the problem arises out of an inability to do the thing, i.e. the whole point is that the purported entry into the contract is not an act of the corporation at all. Section 18 does not seem to be broad enough to encompass this situation with the exception, possibly of Section 18(e). However, if the Sections $16(3)$ and $18(\mathrm{e})$ are broad enough, the test that must still be satisfied is whether the lender did not, by virtue of its position or relationship have, or ought to have had, knowledge of the facts which would have made the lack of voting authority apparent. Where the person dealing with the corporation is aware that the directors have an interest it may well be encumbent upon that person to satisfy himself that the directors are entitled to vote and, if not, that the corporation actually agreed to the contract.

15. In $R$. v. Champ (1982) 83 D.T.C. 5029, a corporation purported to declare dividends on one class of shares to the exclusion of the other class. Certainly, neither the corporation nor its shareholders or, presumably, even its creditors had any objection to that. However, Revenue Canada was successful in establishing that as a matter of corporate law (and, arguably, quite independently of income tax law) this could not be done because of deficiencies in the constitution of the company. The question arises, then, whether a marginally more aggressive Tax Department could not use other corporate law arguments to uphold the position that transactions which purportedly took place were not actually perfected.

16. Section 114.

17. Section 113. 
Even if one accepts the proposition that directors' liabilities have been expanded under the Business Corporations Act, it appears, for the present at least, that there is a very simple way of avoiding part, if not all, of these liabilities.

For companies governed by the Companies Act, it was generally thought that the directors could not enter into contracts which would fetter their discretion. This principle was generalized into a statement that the shareholders could not enter into agreements which dealt with the exercise of directors' powers. This statement was probably incorrect in its generality as properly drafted articles of association could, even under the Companies Act, have returned the directors' powers to the shareholders who could then agree as to how the powers were dealt with. Under the Business Corporations Act, the whole question has been clarified. Section 140 of the Business Corporations Act now provides that the powers of the directors can be abrogated and assumed, in whole or in part, by unanimous agreement of the shareholders. It probably remains the case that the directors cannot, on their own, fetter their discretion but, to the extent that the shareholders have unanimously agreed, the directors' powers can be exercised by the shareholders in such fashion as the agreement provides.

What is significant about Section 140 , insofar as directors' liabilities are concerned, is that Section 140(9) goes on to provide that, to the extent that the directors' powers have been abrogated, any liability of the directors is thereby assumed by the shareholders. Section 140(7) provides as follows:

140(7) A shareholder who is a party or is deemed to be a party to a unanimous shareholder agreement has all the rights, powers and duties and incurs all the liabilities of a director of the corporation to which the agreement relates to the extent that the agreement restricts the powers of the directors to manage the business and affairs of the corporation, and the directors are thereby relieved of their duties and liabilities, including any liabilities under Section 114 to the same extent.

It follows, therefore, that an operating company can be incorporated with a single corporate shareholder. That single corporate shareholder (call it "Holdco") can enter into an unanimous shareholder agreement with the operating company (call it "Opco") in which all the directors' powers are abrogated and given to Holdco. It follows that all liabilities which would formerly have rested with the individual directors of Opco would now rest with this single shareholder which, of course, has limited liability. There is nothing in the legislation which would pass liabilities on to the directors of Holdco.

The arrangement is not as awkward as it first appears. Prior to the unanimous shareholder agreement the decisions of Opco, in theory, would have to have been made by its directors in meeting. Holdco now makes those decisions and Holdco, in theory, exercises these decisions through its board of directors. All that has happened, therefore, is that the directors of Holdco have replaced the directors of Opco without any of the attendant liabilities. Certainly, there are disadvantages to the extent that there are extra legal and accounting expenses which may be incurred. One would expect, therefore, that the scheme would only be utilized where the operation is labour intensive or where there is otherwise more than a nominal risk of director liability. One must assume, 
also, that there is a rather substantial risk that the legislation may, at some point, be amended in some fashion.

It should be noted, however, that it is probably the case that Opco must appoint at least one director, at least initially. ${ }^{18}$ As this director would not be exercising any powers, he would not be inçurring any liabilities with respect to actions taken by the corporation. However, as a director, the particular individual would presumably still owe a special duty to the corporation arising out of his fiduciary relationship with it. Furthermore, Section 140(5) would not relieve the director from any liabilities he might incur under federal legislation. ${ }^{19}$

\section{DELEGATION}

There may be a deficiency in the Business Corporations Act which may render it impossible for a corporation to appoint agents in certain circumstances.

Under the Companies Act it is the directors who have the ability to exercise the company's rights and powers except in those rare circumstances where the articles of association provide otherwise. The mind of the corporation is comprised of the Board of Directors and every decision they properly exercise is a decision of the company. This remains the case under the Business Corporations Act. ${ }^{20}$ However, it may be impractical for the directors to be involved in every decision required to be made by the company. Under the Companies Act, it is generally accepted that the directors can delegate their powers to other persons but only to the extent provided under their company's articles of association. In the absence of such an enabling provision the maxim delegatus non potest delegare applies and no such power of delegation exists. ${ }^{21}$ A person dealing with an agent of a Companies Act company lacking such a provision in its articles could find himself in some difficulty in later enforcing that contract if it was apparent to that person that the agent was the person making the decision. ${ }^{22}$ Similarly, the company could also be in difficulty if the other party revoked its offer or otherwise repudiated the purported contract before the directors of the Company properly ratified the acts of the agent. In such a situation the corporation would not have exercised a decision in the matter and there would not, at that point in time, be a contract. Furthermore, the indoor management rule might not be of

18. Section $97(2)$ provides that a non-distributing corporation "shall" have one or more directors. Section 101(3) further provides that the shareholders "shall" elect directors to hold office until the next meeting. Of course, these sections do not prevent a director from resigning.

19. See, for example, Section 227.1 of the Income Tax Act which imposes upon directors liability for monies which the corporation has failed to withhold for employees' tax, Canada Pension Plan or U.I.C. contributions.

20. Section 97(1).

21. Howards Case (1866) I Ch. App. 561; Horn v. Faulder (Henry) \& Co. (1908) 99 L.T. 524; Re County Palatine Loan and Discount Co. (1874) 9 Ch. App. 691.

22. The rule does not, of course, prohibit the delegation of purely formal or administrative acts. In those cases, the agent would only be carrying out the directions of the Board of Directors and would not be exercising a discretion. 
assistance to the third party as the constructive notice doctrine ${ }^{23}$ would fix him with actual knowledge of the articles of association and hence of the directors' inability to delegate their powers.

For these reasons, it is common for the articles of association of Companies Act companies to contain provisions which permit the delegation of powers to others. Such a provision might read as follows:

The directors may from time to time, by power of attorney under the seal of the company appoint any company, firm or person whatsoever, or any fluctuating body of persons, whether nominated directly or indirectly by the directors, to be the attorney or attornies of the company for such purposes and with such powers, authority, and discretion (not exceeding those for the time being vested in or exercisable by the directors under these presents) and for such period and subject to such conditions as the directors think fit.

It is significant that the above provision allows for delegation to persons other than directors.

There is no reason, it is suggested, for supposing that the maxim delegatus non potest delegare is inapplicable to companies governed by the Business Corporations Act. However, for corporations governed by the Business Corporations Act the directors are given some powers of delegation statutorily. Section 110(1) provides as follows:

$110(1)$ Directors of a corporation may appoint from their number a managing director, who must be a resident Albertan or a committee of directors and delegate to the managing director or committee any of the powers of the directors.

However, the phrase "from their number" restricts this power of delegation to directors only. Section 116 , on the other hand, provides as follows:

116 Subject to the articles, the by-laws or any unanimous shareholder agreement,

(a) The directors may designate the offices of the corporation, appoint as officers individuals of full capacity, specify their duties and delegate to them powers to manage the business and affairs of the corporation, except powers to do anything referred to in Section 110(3).

The question that then arises is what is meant by the term "officer". Certainly there are very strong arguments to be made that the word "officer" (which is not defined in the Business Corporation Act) is restricted to senior positions of a more or less permanent nature as, for example, the offices of president and secretary. Major textbooks on company law ${ }^{24}$ use the term in this restrictive sense and there is judicial authority which would support this narrower interpretation, at least under the Companies Act. ${ }^{25}$ Certainly, the use of the word "of fice" in Section 116 itself implies a position of a more or less permanent nature and not a position of agency for a specific purpose. Also, it is clear from Section 1(j.1) that the term "individual" excludes corporations. At the very least, then, there is a very good argument to be made for the proposition that there is nothing in the Business Corporations Act which allows directors to delegate their

23. Ernest v. Nicholls (1857) 10 E.R., 1351; Peel's Case (1867) 2 Ch. App. 674; Mahoney v. East Holyford Mining Co. (18975) L.R.H.L. 869.

24. See, for example, Gower's Principles of Modern Company Law, 4th Ed. and Penningtons Company Law, 4th Ed.

25. See Re Western Counties Steam Bakeries and Milling Co. [1897] 1 Ch. 617 (C.A.); Cornell v. Hay (1897) L.R. 8 C.P. 283; Openshaw v. Fletcher (1916) 32 T.L.R. 372 (C.A.); Re Great Wheal Polgooth Co. (1883) 53 L.J. Ch. 42; Carter's Case (1886) 31 Ch. D. 496. 
powers to persons who are not directors or officers as the term is used in the restrictive sense and in no event to another corporation..$^{26}$

The issue is not going to be of practical concern in the majority of cases. For one thing it is normally going to be a director or officer of a corporation that will negotiate a material contract on the corporation's behalf and then purport to exercise a discretion in making or accepting an offer to enter into that contract. The Business Corporations Act permits delegation to of ficers and directors and the question of authority in such cases would, therefore, be governed by the more clearly understood principles of apparent authority and the applicability of the indoor management rule. ${ }^{27}$

However, there are going to be situations where the question will arise. Corporations do sometimes purport to act as agents for others as for example where a corporate trustee purports to act as trustee and agent for a group of corporate joint venturers. Solicitors sometimes act as agents for corporate clients in negotiating settlements or in making amendments to existing contracts within broad parameters of authority. Professional agents may purport to contract on behalf of undisclosed corporate principals.

The concern this creates for persons dealing with corporations, particularly where the purported agent is making an apparent exercise of discretion, and even more so where the other party (for example, a lender) has an intimate knowledge of the corporate make-up of the corporation, is obvious. However, the corporation itself will normally have an interest in preserving the purported contract and the question of the ability of the other party to repudiate will not normally arise until the other party has purported to do so and, presumably, before any thought has been given to ratification of the agent's acts.

For corporations with a relatively small number of shareholders, the solution, once again, is a simple one. Section 97(1) provides that the exercise of powers by the directors is subject to any unanimous shareholders agreement. Hence, it is suggested that a prudent practice would be for simple forms of unanimous shareholder agreements to be entered into as a matter of corporate constitution which specifically authorize the delegation of directors' powers to corporations and to individuals who are not of ficers or directors.

Where the number of shareholders makes a unanimous shareholder agreement impractical the problem becomes much more difficult. It may be possible to provide for delegation by enacting a by-law for that purpose but the ability to do so, once again, is unclear. The difficulty is that

26. It may, of course, be argued that the authority granted to the directors under section $97(1)$ of the Business Corporations Act to manage the business and affairs of the corporation must necessarily involve an implicit power to appoint agents and to delegate discretionary powers to those agents. However, it would seem that the same argument ought to be equally applicable to companies governed by the Companies Act and there is clear authority to the contrary (see note 21 ). Also, if such an ability to delegate is implicitly granted under s. 97(1) then sections 110 and 116 are redundant.

27. If the person purporting to act as agent is a corporation or is not a director or officer it is a nice question whether the apparent authority doctrine can be successfully applied since the question is not one of the appearance of authority but of the legal ability to grant it. 
there is nothing in the Business Corporations Act which specifically authorizes such a provision and unless the authority for such a provision can at least be implied then it is suggested that any such by-law would be ineffectual. ${ }^{28}$ The only section of the Act which might imply this authority is the general one contained in Section 98(1) which provides for the enactment of by-laws that regulate the business and affairs of the corporation. However, it is not clear, first of all, whether section 98(1) contemplates the enactment of any by-laws not authorized elsewhere in the Act, although it is suggested that the better view is that it does. Second, it is not clear whether delegation can be said to fall within the meaning of the words "business" or "affairs" although it is suggested, once again, that the better view is that it does. While "affairs" is defined in such a way ${ }^{29}$ that it probably does not contemplate delegation, "business", which is not defined, particularly in view of the definition given to "affairs", probably contemplates dealings between the corporation and other parties and hence probably includes delegation to agents.

\section{THE AUTHORITY OF ARTICLES OF ASSOCIATION FOLLOWING CONTINUATION}

Generally speaking, the powers of a director of a company governed by the Companies Act are determined by the articles of association. The Business Corporations Act does not, however, recognize the existence of such a document. The Business Corporations Act, rather, provides for three forms of documents dealing with the constitutional aspects of the company; namely the by-laws, the articles of incorporation (or articles of continuance as the case may be) and the unanimous shareholder agreement.

It is suggested that the by-laws of a Business Corporations Act company and the articles of association of a Companies Act company are fundamentally different in nature. ${ }^{30}$ Hence in situations where the articles of association of a Companies Act company have neither been specifically repealed or specifically adopted as by-laws ${ }^{31}$ a very perplexing question arises as to what effect, if any, the articles of association have following continuance.

There are strong arguments in favour of the position that the articles of association cease to have any effect upon continuation, at least if they are not specifically adopted as by-laws and it is suggested that this is by far the better view. Quite simply, the Business Corporations Act does not recognize or authorize any such thing as articles of association. Furthermore, once the company is continued, Section $29^{32}$ of the Companies Act

28. For arguments in support of this proposition see the author's note in the Alberta Law Review Vol. XXI, No. 1, 381.

29. Section 1 (a).

30. Once again for arguments in support of this proposition see the author's note in the Alberta Law Review Vol. XXI, No. 1, 381.

31. It may be that many of the provisions formerly found in articles of association may not be validly contained in by-laws. See Supra n. 30 .

32. Section 29(1) of the Companies Act provides that the articles of association "when registered, bind the company and the members thereof to the same extent as if they respectively had been signed and sealed by each member and contained covenants on the part of each member ... to observe all the provisions of [the articles of association] subject to the provisions of [the Companies Act]". 
ceases to have any effect upon that company. Section 29 is the operative section of the Companies Act which makes the articles of association binding upon a company's shareholders. There is no similar section in the Business Corporations Act. Also, under the Business Corporations Act, the complete absence of by-laws results only in the application of statutory provisions in their place and hence there is no implied continuation of the articles of association by reason of necessity.

However, the question is not completely beyond doubt. For one thing, there is nothing in the Business Corporations Act which specifically states that upon continuation the articles of association are deemed repealed. Secondly, while the articles of association and by-laws are fundamentally different in nature, there are, nonetheless, some similarities in allowable content. Many of the things that were formerly contained in the articles of association can legitimately be contained in the by-laws. ${ }^{33} \mathrm{It}$ is even conceivable that the articles of association become, by definition, a unanimous shareholder agreement upon continuance. The definition of a unanimous shareholder agreement under Section $1(\mathrm{z})$ of the Business Corporations Act is "a written agreement to which all the shareholders of a corporation are or are deemed to be parties". Hence, if the original subscribing members are all the shareholders of the corporation at the time of continuance, there is an argument for saying that the articles now form a unanimous shareholder agreement. For that matter, Section 29 of the Companies Act, immediately prior to continuance, has the effect of making the articles of association an agreement between all shareholders for the time being and perhaps then it is a document to which all the shareholders "are deemed to be parties" at the time of continuance.

This can create quite a bit of uncertainty. In dealing with a corporation where the articles of association have not been specifically repealed there is a question as to the extent of the directors' powers and the ability of the directors to delegate. Indeed, there may be any number of provisions contained in the articles of association which purport to govern the business and affairs of the corporation and the relationship between shareholders, the applicability of which are matters of considerable importance. For corporations recognizing this problem a further difficulty arises in how to deal with it after continuation. ${ }^{34}$ Certainly the prudent and safest way to deal with the matter would be to have the shareholders unanimously agree that the articles of association are now at an end. Hence, if the articles of association did comprise a unanimous shareholder agreement, that would be effective. If they only comprised by-laws (if indeed they had any effect at all) then it would be sufficient for the directors (followed by an ordinary resolution of shareholders ${ }^{35}$ ) to simply repeal them, though this would not be without risk.

The problem is a little more complex for persons dealing with the corporation since they will not know whether they should be paying heed to

33. See Supran. 31.

34. Prior to continuation the articles of association could, presumably, have been repealed (effective the date of continuance) by special resolution under the authority of section 55(1) of the Companies Act.

35. Section 98(2). 
the articles of association or not. Even if by-laws have been passed the articles of association may not have been specifically repealed and there may be provisions in the articles which are not addressed or which cannot legitimately be addressed by by-law. In other words, there may not be any repeal by implication. There is some relief provided by Section 17 of the Business Corporations Act which purports to repeal the constructive notice doctrine. Presumably, because of Section 17, persons dealing with the company will no longer be deemed to have knowledge of the contents of the articles of association by reason only that they are on record at Companies Branch. However, it is significant to note the use of the words "by reason only". There is nothing in Section 17 which would preclude arguments being raised against parties who have dealt with corporations when they knew or ought to have known the contents of the articles of association. This would be a particular problem for lenders who may have had dealings with a corporation on an on-going basis prior to the time that the company was continued. It may be that at some time in the past the lender was actually provided with the articles of association or had its solicitors conduct searches of the articles in connection with an earlier loan.

\section{SECTION 117(3)}

Section 117(3) of the Business Corporations Act reads as follows:

Subject to Section 140(7), no provision in a contract, the articles, the bylaws, or a resolution relieves a director or officer from the duty to act in accordance with this Act or the regulations or relieves him from liability for a breach of that duty.

There are a number of situations where this provision will alter certain practices formerly conducted under the Companies Act. Consider the following examples:

1. Upon the sale of a shareholder's shares in a company governed by the Companies Act the shareholder or its nominee as the case may be would, of course, resign as director. To avoid any lingering liabilities, it was prudent for the vendor shareholder to obtain from the corporation a broad form of release releasing the director from any possible head of liability arising out of his directorship. This would no longer appear to be possible. While there would not appear to be much harm in attempting such a release (provided that the release is severable from the rest of the contract) it is probably the case that the only form of enforceable protection that can be obtained would be an indemnity from the remaining shareholders in respect of any actions which might be brought by the corporation..$^{36}$ An additional or alternative method might be the obtaining of an admission by the corporation that the retiring director has not breached any obligations to the corporation though obviously such an admission would likely be inapplicable to any matters then unknown.

2. There are occasionally situations where the directors are called upon to resolve to do an act on behalf of the corporation which arguably, or even blatantly, is not in the best interests of the company. The act might, for example, be in the best interests of the shareholders or of

36. A similar indemnity could not be obtained from the corporation itself. See Section 119. 
another party in which the shareholders have an interest. Section $117(1)$ imposes an obligation upon the directors to act in the best interests of the company. ${ }^{37}$ Hence a resolution to carry out the act carries some risk of liability for those directors acquiescing in it, and Section 117(3) puts serious doubts upon the ability of the directors to obtain a contractual release from the corporation in respect of these acts. One mechanism relied upon under the Companies Act was for the shareholders to subsequently ratify the act. However, the words "or a resolution" in Section 117(3) have placed some doubts even upon this method. ${ }^{38}$ Another possibility would be for the shareholders themselves to exercise the decision. However, this method is not without difficulty either. For one thing, Section 97(1) gives all the decision making power to the directors subject only to the terms of a unanimous shareholder agreement. Hence the shareholders may be powerless to exercise the decision unless there is a provision in a unanimous shareholder agreement allowing them to do so or, possibly, if all the directors are prohibited from voting on the matter for other reasons. ${ }^{39}$ However, to the extent that the powers of the directors have been usurped by the shareholders under a unanimous shareholder agreement, Section 140(7) imposes the directors' obligations upon the shareholders. It is unclear, but certainly arguable, that among the liabilities assumed by the shareholders under Section $140(7)$ are those contained in Section 117(1) and, in particular, the obligation to act in the best interests of the company.

3. In any situation where a director is sued by his corporation for alleged wrongful acts settlement is likely a common goal. However, any settlement would naturally have to be accompanied by a release of the director and Section 117(3) puts the validity of any such release into question. It might be that the only way to resolve the matter would be by consent judgment. Although that may be irrevocable by the cor-

37. Section $117(4)$ is often misinterpreted. Section $117(4)$ allows a director, in determining whether a particular transaction or course of action is in the best interests of the corporation, to give special consideration to the interests of the shareholders who appointed him. However, this only applies if he is appointed by the holders of a class or a series of shares and not simply because he is appointed by a particular shareholder pursuant to, say, a unanimous shareholder agreement.

38. Ratification by the shareholders may no longer be effective anyway. See page ? of this article, supra.

39. See supra n. 6 and page ? of this article. 
poration, ${ }^{40}$ a consent judgment carries with it an implication of guilt ${ }^{41}$ and hence it is a method which has highly undesirable aspects.

\section{CONCLUSION}

It is worth noting that the unanimous shareholder agreement figures prominently in dealing with the concerns raised above. Quite aside from its utility in dealing with the relationships between shareholders general$l y$, the unanimous shareholder agreement can also serve as a document of corporate constitution. At least in cases where the number of shareholders makes such an agreement practical, and particularly where entered into at the time of incorporation, it provides a simple and economic method of removing the concerns canvassed above.

40. Canada Permanent Corporation v. Christenson [1929]2 W.W.R. 198; Kinch v. Walcott [1929] 3 W.W.R. 13.

41. A consent judgment would, of course, have to be filed and would become a matter of public record. A contract of release would not be public and, in any event, would likely contain an express acknowledgement by the corporation that there has been no admission of any wrong doing. 